\title{
STUDI TEMPAT BERTENGGER BURUNG CIKALANG DI SUAKA MARGASATWA PULAU RAMBUT
}

\author{
Putri Kesuma Wardhani ${ }^{1}$, Paskal Sukandar ${ }^{2}$, dan Hanum Isfaeni ${ }^{2}$ \\ ${ }^{1}$ Prodi Biologi FMIPA Universitas Negeri Jakarta, Indonesia. ${ }^{2}$ Program Studi Pendidikan Biologi FMIPA \\ Universitas Negeri Jakarta, Indonesia \\ Email: wardhani_putrikesuma@yahoo.com
}

\begin{abstract}
Frigatebird is one of seabird species found in Pulau Rambut Wildlife Reserve (SMPR). The bird activities include roost in fish pole, flying, foraging in the ocean and also roost in SMPR at night. The aim of this research was to know roosting site used by frigatebird while at SMPR. This research was conducted in SMPR, Jakarta on August and September 2010 by using descriptive method and survey techniques. Data was collected directly on the object of research. Frigatebird population was calculated directly by counting individuals one by one as they flew low in the air over SMPR. Frigatebird roosting site was also researched directly by observing frigatebird when going to roost. Furthermore, analysis vegetation was also conducted on trees in roosting site. From this research can be known that the frigatebird population in SMPR ranged between 87-193 birds. Frigatebird utilize Sterculia foetida tree to be used as a place to roost. This roosting site located in mixed secondary forest to the west and south SMPR close to mangrove forest. Average of height and diameter S. foetida tree that is used to roost is $23,47 \mathrm{~m}$ and $42,26 \mathrm{~cm}$. There are 3 species of tree that dominate in frigatebird roosting site namely Ficus sp. (INP 16,91\%), Allophylus cobbe (INP 16,78\%) dan Diospyros maritima (INP 14,23).
\end{abstract}

Key words: frigatebird, Pulau Rambut Wildlife Reserve (SMPR), roosting site

\section{PENDAHULUAN}

Pulau Rambut merupakan salah satu pulau yang terdapat di gugusan Kepulauan Seribu dan ditetapkan sebagai suaka margasatwa. Suaka Margasatwa Pulau Rambut (selanjutnya disingkat SMPR) memiliki tiga tipe hutan yang beragam, yaitu hutan pantai, hutan mangrove dan hutan sekunder campuran. Kondisi habitat ini mendukung kehidupan berbagai jenis burung sebagai lokasi berbiak, mencari makan, beristirahat, bertengger atau jalur perlintasan bagi burung migran. Jenis burung di SMPR beranekaragam, ada burung air, burung terrestrial dan burung laut (Imanudin dan Mardiastuti, 2003).

Jenis burung laut yang tercatat di SMPR, yaitu dara laut dan cikalang. Ada 2 jenis burung cikalang di SMPR, yaitu Cikalang Christmas dan Cikalang Kecil (Fitriana 1999; Rombang dan Rudyanto, 1999; Imanuddin dan Mardiastuti, 2003; BirdLife International, 2001; BirdLife International, 2004). Burung cikalang bukan merupakan jenis penetap ataupun endemik Indonesia. Cikalang Christmas diketahui hanya berbiak di Pulau Christmas, Samudera Hindia. Sedangkan Cikalang Kecil tercatat berbiak di beberapa pulau di sekitar Samudera Hindia dan Samudera Pasifik. Burung Cikalang digolongkan sebagai jenis yang dilindungi. Oleh IUCN Red List, jenis Cikalang Christmas dikategorikan sebagai jenis yang Critically Endangered, sedangkan Cikalang Kecil berstatus Least Concern (BirdLife International, 2009). Bahkan oleh CITES, jenis Cikalang Christmas digolongkan dalam Appendix I. Di Indonesia, 
burung Cikalang Christmas dilindungi oleh UU No.5/1990 dan PP No.7/1999 (Sukmantoro dkk, 2007).

Burung cikalang bersifat aerial dan diurnal. Di SMPR, burung cikalang teramati aktif pada siang hari, terbang tinggi berputar-putar, meluncur di atas laut dan bertengger di atas tonggak-tonggak bambu pada sero ikan di perairan sekitar SMPR, terkadang burung cikalang menyerang jenis burung lain untuk merebut makanan. Ketika sore, burung cikalang terlihat terbang tinggi berputar-putar di atas SMPR dalam kelompok yang besar. Kemudian pada malam hari bertengger dan beristirahat di SMPR. Namun informasi mengenai aktivitas bertengger burung cikalang di SMPR ini masih terbatas, terutama mengenai kemungkinan tempat yang dipilih burung cikalang sebagai tempat bertengger. Bertengger sendiri merupakan salah satu perilaku burung yang dilakukan berdiri atau duduk di suatu tempat dengan tujuan beristirahat atau tidur (Campbell and Elizabeth 1985; Elbroch et al., 2001). Sedangkan tempat bertengger umumnya mengacu pada tempat yang aman dimana burung dapat beristirahat. Burung dapat memanfaatkan berbagai jenis objek untuk dijadikan tempat bertengger, seperti pohon, batu karang, tebing, kabel, pasir pantai bahkan di salju.

Penelitian ini dilakukan guna mengetahui kemungkinan tempat yang dipilih dan digunakan oleh burung cikalang untuk bertengger dan beristirahat selama berada di SMPR. Selain dapat dijadikan sebagai informasi tentang daerah sebaran atau distribusi burung cikalang, data hasil mengenai tempat bertengger burung cikalang di SMPR ini dapat juga digunakan dalam penentuan kebijakan konservasi yang lebih lanjut tentang jenis burung cikalang secara khusus dan SMPR secara umum.

\section{METODE PENELITIAN}

Penelitian ini dilakukan di Suaka Margasatwa Pulau Rambut, Kepulauan Seribu, Jakarta pada bulan Agustus dan September 2010. Metode yang digunakan adalah metode deskriptif dengan teknik survei yaitu melakukan pengamatan secara langsung tanpa memberikan perlakuan khusus pada objek penelitian.

Alat dan bahan yang digunakan, yaitu teropong binokuler Bushnell, kamera digital Casio Exilim EX-Z60, kompas Brunton, meteran gulung, senter, alat pengukur waktu (jam tangan), Weather Meter Kestrel, GPS (Global Positioning System) Garmin eTrex, lembar pengamatan, alat tulis dan tali raffia.

\section{POPULASI BURUNG CIKALANG}

Pengamatan dan penghitungan dilakukan di menara pandang SMPR. Lokasi ini dipilih karena strategis dan berada cukup tinggi, sehingga hampir seluruh bagian SMPR dapat teramati, begitu pun ketika burung cikalang terbang di atas pulau, bisa dilihat dengan jelas. Penghitungan dilakukan dengan menghitung burung cikalang secara langsung satu per satu, setiap individu dalam kelompok terbangnya ketika sedang berputar-putar kemudian meluncur di atas SMPR dan melintasi menara pandang. Selain itu diamati juga arah kedatangan burung cikalang serta arah pergerakannya selama terbang di atas Pulau Rambut. Penghitungan dilakukan selama lima kali pengamatan yang dimulai pukul 16:40-18:10 WIB dengan interval waktu pengamatan per 10 menit. Hasil populasi burung cikalang selanjutnya dihitung dengan statistik sederhana untuk mengetahui rata-rata jumlah burung cikalang yang teramati dan standar deviasinya.

\section{IDENTIFIKASI TEMPAT BERTENGGER DAN VEGETASI DI SEKITARNYA}

Penelitian diawali dengan pencarian tempat bertengger melalui observasi langsung, yaitu mengikuti burung cikalang ketika teramati sudah terbang rendah menuju ke tempat bertenggernya pada malam hari. Penentuan tempat 
bertengger dilakukan ketika burung cikalang terlihat sudah pasti hinggap dan bertengger. Lalu tempat bertengger tersebut diberi tanda.

Di setiap tempat bertengger burung cikalang juga didata titik koordinat lokasinya dengan menggunakan GPS. Data titik koordinat tempat bertengger ini kemudian diolah dengan bantuan software ArcView 3.3. Hasilnya berupa gambar peta SMPR yang dilengkapi dengan titik-titik lokasi tempat bertengger. Dari gambar peta tersebut dapat diketahui sebaran tempat bertengger yang dipilih burung cikalang ketika berada di SMPR.

Di setiap tempat bertengger burung cikalang diletakkan plot dengan tempat bertengger sebagai pusatnya. Kemudian dilakukan pendataan karakteristik vegetasi yang terdapat di sekitarnya. Kategori vegetasi yang juga di data karakteristiknya yaitu yang berupa pohon dan memiliki diameter lebih dari $10 \mathrm{~cm}$. Adapun data-data yang diambil adalah jenis pohon, diameter setinggi dada (DBH), dan tinggi total.

Hasil pendaatan karakteristik vegetasi di sekitar bertengger burung cikalang ini kemudian dihitung untuk mengetahui kerapatan, dominansi dan frekuensi tiap jenis vegetasi. Hasil penghitungan kemudian dibandingkan antar tiap jenis sehingga masing-masing diperoleh nilai relatifnya. Selanjutnya bisa diketahui indeks nilai penting (INP) tiap jenis dengan menjumlahkan nilai kerapatan relatif, dominansi relatif, dan frekuensi relatif. Dari hasil INP

ini dapat diketahui jenis yang paling mendominasi dan berkontribusi di tempat bertengger burung cikalang. Rumusrumus yang digunakan untuk menganalisis vegetasi mengikuti Cox (1967).

Data-data yang diperoleh dalam penelitian ini dianalisis secara deskriptif.Data populasi burung cikalang di SMPR disajikan dalam bentuk tabel dan grafik peningkatan jumlah burung cikalang. Data tentang tempat bertengger ditampilkan dalam bentuk gambar peta SMPR yang dilengkapi dengan titik-titik lokasi tempat bertengger burung cikalang. Sedangkan data analisis vegetasi di sekitar tempat bertengger burung cikalang di sajikan dalam bentuk tabel dan grafik jenis-jenis pohon serta perbandingan INP tiap jenis pohon.

\section{HASIL}

POPULASI BURUNG CIKALANG DI SMPR

Penghitungan populasi dilakukan pada sore hari ketika burung cikalang teramati terbang menuju SMPR dan berputar-putar di atas pulau sampai saat burung cikalang turun menuju ke tempat bertengger.Waktu penghitungan berlangsung antara pukul 16:40 dan 18:10 WIB. Adapun populasi burung cikalang dapat dilihat tabel 1 berikut:

Berdasarkan hasil pengamatan, populasi terbanyak burung cikalang yang berhasil dihitung yaitu 150 ekor dan populasi paling sedikit hanya 2 ekor. Rata-rata populasi burung cikalang selama lima kali pengamatan adalah 113 ekor (SD 26). Dari hasil penghitungan rata-rata tersebut, maka dapat diperkirakan populasi burung cikalang di SMPR berkisar antara 87 sampai 139 ekor.

Burung cikalang mulai teramati terbang menuju SMPR antara pukul 16:30-16:40 WIB.Antara pukul 17:3018:10 WIB, populasi burung cikalang yang menuju SMPR semakin meningkat.Hubungan antara peningkatan populasi burung cikalang dengan bertambahnya waktu dapat dilihat pada gambar 1 .

Dari grafik di atas diketahui bahwa jumlah burung cikalang mengalami peningkatan mulai pukul 17:30 dan mencapai jumlah tertinggi antara pukul 18:00-18:10 WIB. Setelah pukul 18:10, tidak terlihat lagi cikalang yang terbang. 


\begin{tabular}{llllll}
\hline \multicolumn{7}{c}{ Tabel 1. Populasi burung cikalang } \\
\hline \multirow{2}{*}{ Jam } & \multicolumn{7}{c}{ Pengamatan hari ke- } \\
\cline { 2 - 6 } & 1 & 2 & 3 & 4 & 5 \\
\hline $16: 40$ & 0 & 0 & 0 & 10 & 0 \\
$16: 50$ & 0 & 0 & 5 & 23 & 0 \\
$17: 00$ & 0 & 0 & 12 & 11 & 0 \\
$17: 10$ & 0 & 0 & 5 & 47 & 0 \\
$17: 20$ & 0 & 22 & 2 & 59 & 0 \\
$17: 30$ & 37 & 17 & 98 & 40 & 55 \\
$17: 40$ & 98 & 76 & - & 45 & 85 \\
$17: 50$ & 76 & 77 & - & 57 & 141 \\
$18: 00$ & 79 & 122 & - & 79 & 150 \\
$18: 10$ & 115 & - & - & - & - \\
Total populasi & 564 & & & & \\
Rata-rata populasi & 113 & & & & \\
\hline
\end{tabular}

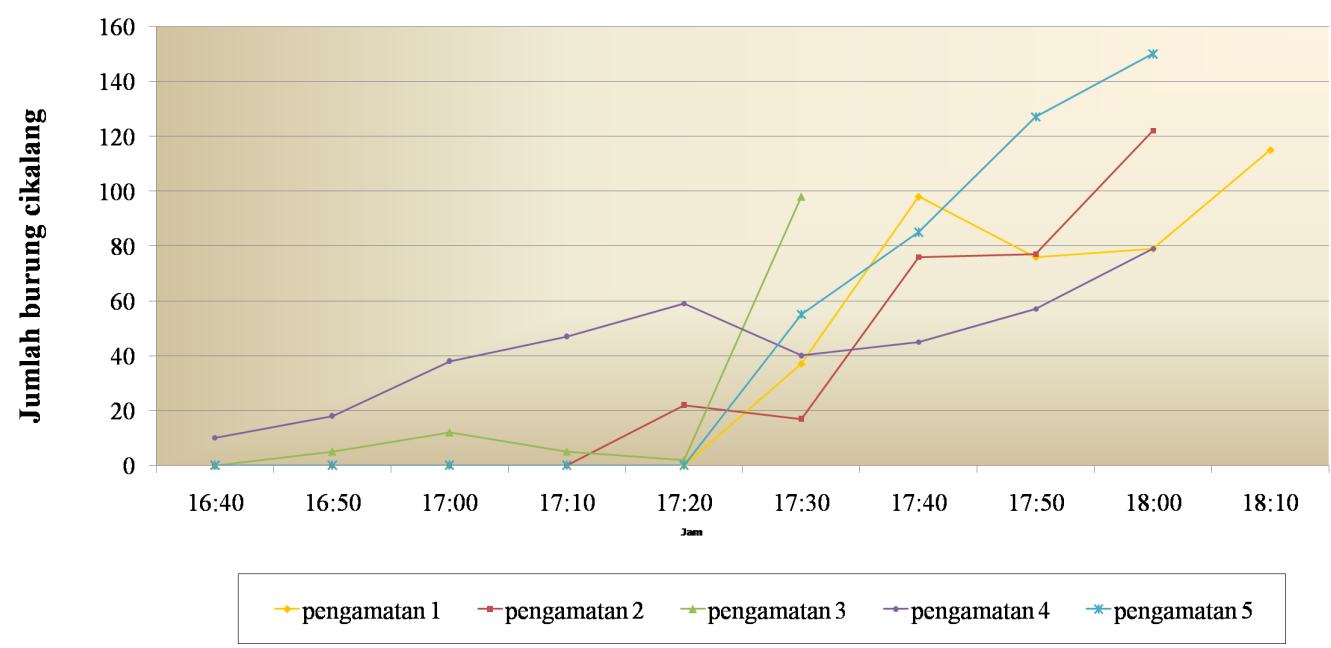

Gambar 1. Grafik peningkatan jumlah burung cikalang dari pukul 16:40-18:10 WIB

\section{TEMPAT BERTENGGER BURUNG CIKALANG DI SMPR}

Pada setiap lokasi ditemukannya tempat bertengger burung cikalang, dilakukan pendataan titik koordinat dengan menggunakan alat GPS. Data titik koordinat ini kemudian ditampilkan ke dalam gambar peta SMPR (Gambar 2), sehingga dapat diketahui sebaran tempat bertengger burung cikalang di SMPR.

Pada gambar 2 terlihat bahwa sebagian besar tempat bertengger burung cikalang berada di sebelah barat SMPR dan beberapa ditemui di sebelah selatan pulau.Tempat bertengger ini berada di hutan sekunder campuran yang lokasinya terletak tidak jauh dari laut dan dekat dengan rawa-rawa hutan mangrove.

Berdasarkan hasil pengamatan, diketahui bahwa burung cikalang memilih dan memanfaatkan pohon sebagai tempat untuk bertengger selama berada di SMPR.Pohon yang digunakan untuk bertengger memiliki ukuran besar dan tinggi.Ada 21 pohon yang dijadikan tempat bertengger oleh burung cikalang di SMPR. 21 pohon tersebut berasal dari jenis tumbuhan yang sama, yaitu kepuh (Sterculia foetida). Pohon-pohon kepuh yang dijadikan tempat bertengger memiliki rata-rata tinggi $42,26 \mathrm{~m}$, rata-rata $\mathrm{dbh} 23,47 \mathrm{~m}$, dan rata-rata basal area $1394,74 \mathrm{~cm}$. 


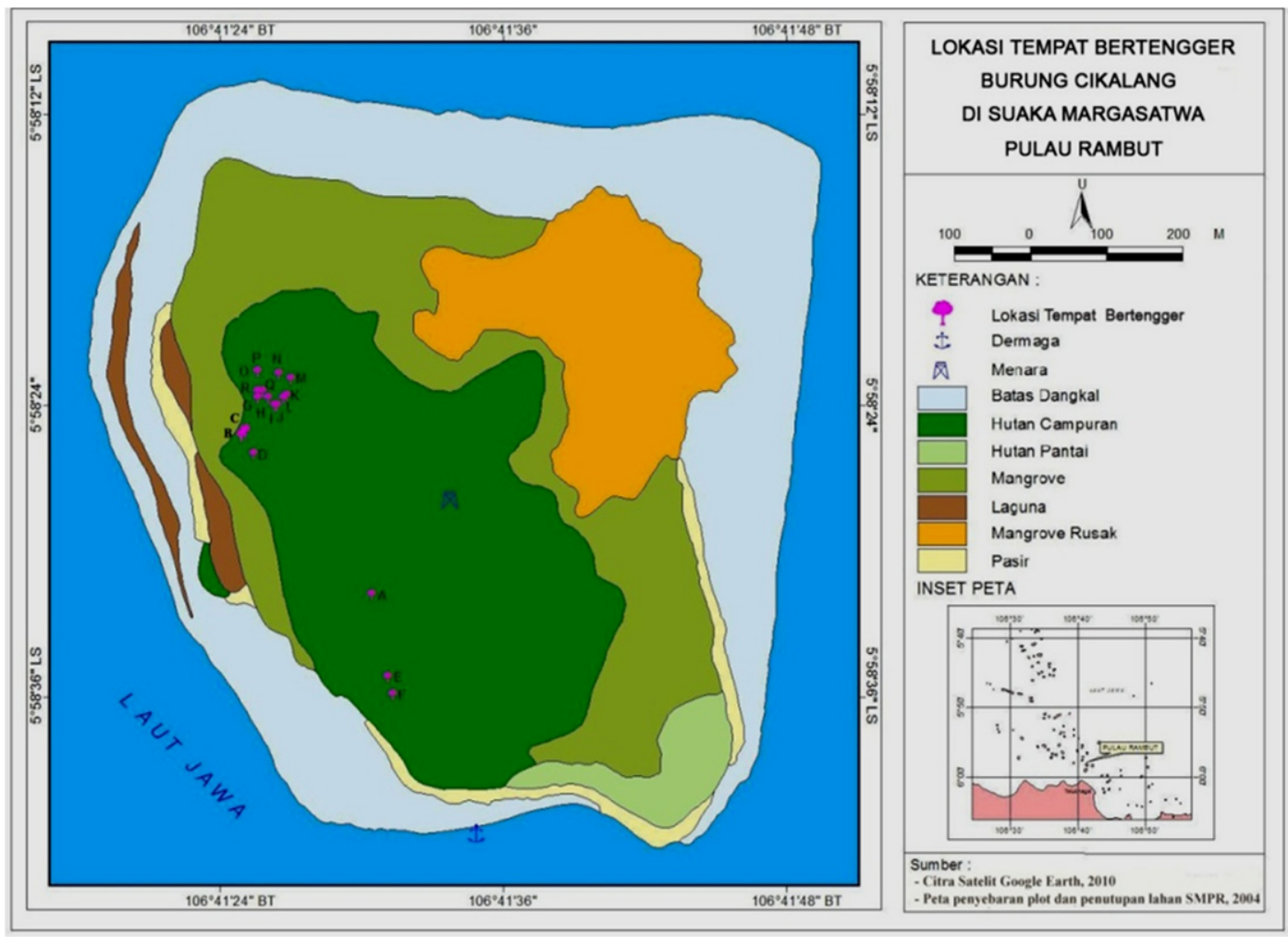

Gambar 2. Pemetaan lokasi tempat bertengger burung cikalang di SMPR

\section{ANALISIS VEGETASI DI SEKITAR TEMPAT BERTENGGER BURUNG CIKALANG}

Analisis vegetasi dilakukan untuk mengetahui jenis-jenis tumbuhan yang terdapat di sekitar tempat bertengger burung cikalang.Selain itu juga untuk mengetahui peranan pohon-pohon tersebut terhadap tempat bertengger burung cikalang atau bagi burung cikalang itu sendiri. Tumbuhan yang terdapat di sekitar tempat bertengger burung cikalang tercatat ada 39 pohon.39 pohon tersebut berasal dari 11 jenis tumbuhan khas hutan sekunder campuran dan satu jenis mangrove. Hasil analisis vegetasi dapat dilihat pada tabel 2.

Dari hasil perhitungan analisis vegetasi pada tabel 1, dapat diketahui jenis pohon yang mendominasi di sekitar tempat bertengger burung cikalang, yaitu beringin kresek (Ficus sp.), koreak (Allophylus cobbe) dan kayu hitam

\begin{tabular}{lllllllll}
\hline \multicolumn{8}{c}{ Tabel 2. Data hasil analisis vegetasi di sekitar tempat bertengger burung cikalang } \\
\hline No. & Jenis pohon & K & KR (\%) & D & DR (\%) & F & FR (\%) & INP (\%) \\
\hline 1. & Beringin kresek (Ficus sp.) & 0,0041 & 0,11 & 1,55 & 6,5 & 0,29 & 10,3 & 16,91 \\
& & & & & & & \\
2. & Koreak (Allophylus cobbe) & 0,0029 & 0,01 & 1,53 & 6,4 & 0,29 & 10,3 & 16,78 \\
3. & Kayu hitam (Diospyros maritima) & 0,0047 & 0,13 & 0,91 & 3,8 & 0,29 & 10,3 & 14,23 \\
4. & Bisoro (Pisonia grandis) & 0,0023 & 0,06 & 0,61 & 2,5 & 0,17 & 6 & 8,56 \\
5. & Kedoya (Dysoxylum amooroides) & 0,0023 & 0,06 & 0,46 & 1,9 & 0,17 & 6 & 7,96 \\
6. & Jati pasir & 0,0017 & 0,04 & 0,35 & 1,4 & 0,17 & 6 & 7,44 \\
7. & Algia & 0,0011 & 0,08 & 0,51 & 2,1 & 0,11 & 3,9 & 6,03 \\
8. & Mindi (Melia azedarach) & 0,0011 & 0,03 & 0,15 & 0,6 & 0,11 & 3,9 & 4,53 \\
9. & Songga langit & 0,0011 & 0,03 & 0,12 & 0,5 & 0,11 & 3,9 & 4,43 \\
10. & Mengkudu (Morinda citrifolia) & 0,0005 & 0,01 & 0,24 & 1 & 0,05 & 1,7 & 2,71 \\
11. & Buta-buta (Excoecaria agallocha) & 0,0005 & 0,06 & 0,13 & 0,5 & 0,05 & 1,7 & 2,21 \\
\hline
\end{tabular}


(Diospyros maritima). Dari keseluruhan plot yang diletakkan di tempat bertengger, ditemukan 8 pohon Diospyros maritima, 7 pohon Ficus sp. dan 5 pohon Allophylus cobbe. Jumlah pohon yang paling sedikit ditemukan di setiap plotnya yaitu mengkudu (Morinda citrifolia) dan buta-buta (Excoecaria agallocha), masing-masing hanya ditemukan 1 pohon.

Ketiga jenis pohon yang mendominasi masing-masing memiliki Indeks Nilai Penting (INP) sebesar 16,91 $\%, 16,78 \%$ dan 14,23 \%. Satu pohon yang merupakan jenis tanaman mangrove, yaitu Excoecaria agallocha memiliki INP $2,21 \%$.

Pada setiap pohon di sekitar tempat bertengger juga dilakukan perhitungan karakteristik pohon seperti tinggi, diameter dan basal area. Berdasarkan hasil perhitungan, pohon-pohon tersebut memiliki kisaran tinggi 3,49-16,07 $\mathrm{m}$ dan diameter 10,46-24,4 cm.

\section{PEMBAHASAN}

\section{POPULASI BURUNG CIKALANG DAN PERGERAKANNYA DI SMPR}

Dari hasil penelitian ini, populasi burung cikalang di SMPR dapat diperkirakan ada lebih dari seratus ekor dengan kisaran antara 87 sampai 139 ekor.Sebagai jenis burung yang bukan penetap, populasi burung cikalang dapat dikatakan cukup besar. Dengan populasi seperti ini, ketika bertengger burung cikalang bersifat communal roosting (bertengger komunal). Birdlife (2001) dan Nelson (2005) juga mengatakan bahwa burung cikalang bertengger secara komunal, yaitu bertengger dalam kelompok besar dengan jumlah burung yang banyak di dalamnya.

Burung cikalang teramati terbang dalam kelompok-kelompok yang cukup besar ketika terbang menuju SMPR pada sore hari untuk kemudian bertengger. Dalam setiap kelompok terbangnya terdapat lebih dari puluhan burung cikalang. Hal ini sesuai seperti yang dinyatakan oleh Harrison (1983); Coates and David (1997) dan MacCormack (2005) bahwa burung cikalang sering teramati berkumpul dalam kelompok terbang dengan jumlah yang besar untuk kemudian bertengger di suatu pulau setelah lewat waktu matahari terbenam.

Selama terbang hingga menjelang waktu turun dan bertengger, burung cikalang teramati melakukan soaring (terbang berputar-putar) dalam kelompok terbangnya, kemudian terbang berurutan dan mulai meluncur (gliding). Pada saat meluncur tersebut, burung-burung cikalang dapat dihitung satu-persatu per individu hingga jumlahnya puluhan bahkan ratusan. Setelah meluncur burung cikalang bergabung lagi dalam kelompoknya dan kembali melakukan soaring. Gaya terbang soaring dan gliding ini umum dilakukan jenis-jenis burung laut seperti burung cikalang. Sesuai dengan yang dinyatakan oleh Nelson (2005) dan BISL (2008), bahwa burung laut memanfaatkan angin di permukaan lautan atau samudera untuk melakukan soaring dan kemudian meluncur (gliding).

Pada saat matahari mulai terbenam, burung-burung cikalang yang sebelumnya terbang terpisah dalam beberapa kelompok akan bergabung menjadi satu kelompok terbang yang besar. Ketika mendekati waktu untuk bertengger, kelompok terbang cikalang tersebut terbagi menjadi dua, masing-masing terbang ke arah yang berbeda, ada yang ke bagian barat dan ada yang terbang ke arah selatan SMPR.

Ketika matahari sudah terbenam dan langit mulai gelap, burung-burung cikalang sudah tidak terlihat lagi terbang di atas SMPR, melainkan mulai terbang rendah dan turun untuk bertengger. Namun berdasarkan hasil pengamatan, burung-burung cikalang tersebut tidak langsung hinggap di pohon walau hari sudah mulai gelap, melainkan masih tetap terbang rendah selama beberapa waktu di atas pohon-pohon tenggeran. Kemungkinan burung 
cikalang baru benar-benar hinggap di pohon dan bertengger saat mendekati waktu tengah malam. Begitu pula ketika burung cikalang meninggalkan tempat bertengger, diduga burung cikalang pergi meninggalkan tempat bertengger tidak lama setelah lewat waktu tengah malam. Hal ini dapat terjadi karena ketika dilakukan pengamatan pada waktu menjelang pagi (pukul 4 pagi) sudah tidak tampak burung cikalang di pohon-pohon tenggeran. Nelson (2005) dan Harrison (1990) juga mengungkapkan bahwa, burung-burung cikalang yang bertengger akan aktif terbang kembali dan meningalkan sarang atau tempat bertenggernya tidak lama setelah waktu dinihari.

\section{TEMPAT BERTENGGER BURUNG CIKALANG DI SMPR}

Burung cikalang dapat memanfaatkan berbagai macam tempat untuk bertengger, seperti pohon, semak atau tebing. Tempat bertengger yang dipilih umumnya terlindung dari predator dengan kondisi angin yang cukup. Bahkan jika keadaan memungkinkan, burung cikalang dapat bertengger di bangunan (tiang), di tanah atau pantai (BirdLife, 2001; McCormack, 2005; Nelson, 2005).

Dari hasil penelitian ini diketahui bahwa burung-burung cikalang yang terdapat di SMPR memilih pohon untuk dimanfaatkan sebagi tempat bertengger ketika bermalam dan beristirahat. Jenis pohon yang dipilih yaitu pohon kepuh (Sterculia foetida). Pemanfaatan pohon kepuh sebagai tempat bertengger diduga berkaitan dengan morfologi burung cikalang serta karakteristik dari pohon kepuh itu sendiri.

Pohon kepuh dipilih sebagai tempat bertengger oleh burung cikalang karena memiliki ukuran yang besar dengan banyak percabangan yang panjang dan kokoh sehingga mampu menopang berat tubuh cikalang. Jenis ini pada umumnya lebih tinggi dibandingkan dengan jenis pohon lain yang terdapat di hutan sekunder campuran SMPR. Pada pohon kepuh, cikalang teramati bertengger di tepi-tepi percabangan strata tengah dan atas yang tajuknya tidak terlalu rapat. Hal ini sangat memudahkan bagi burung cikalang saat bertengger, cikalang tidak akan mengalami kesulitan ketika mendarat atau terbang karena sayapnya dapat bergerak bebas. Kondisi pohon kepuh yang tinggi juga menyediakan cukup angin bagi cikalang untuk memulai terbang kembali setelah bertengger. Gibson (1947); Garnett and Gabriel (2000) pun menyatakan hal yang sama, bahwa burung cikalang menggunakan pohon yang cukup tinggi sebagai tempat bertengger atau bersarang dengan kondisi angin yang memadai.

Rata-rata tinggi pohon kepuh yang digunakan cikalang untuk bertengger ketika berada di SMPR, yaitu 23,47 $\mathrm{m}$, ini hampir sama dengan rata-rata tinggi pohon yang digunakan burung cikalang untuk bersarang di habitat aslinya di Pulau Christmas. Stokes (1988); Nelson (2005); Hill and Dunn (2004), menyatakan jenis pohon yang umum digunakan oleh burung cikalang di habitat aslinya adalah Terminalia catappa, dan Celtis timorensis yang memiliki kisaran tinggi 7-30 m di atas tanah. Di SMPR pun ada jenis pohon Terminalia catappa, namun jenis ini tidak begitu banyak jumlahnya dan berukuran tidak terlalu tinggi bila dibandingkan dengan pohon kepuh. Hal ini mungkin juga menjadi salah satu alasan yang menyebabkan burung cikalang lebih memilih pohon kepuh sebagai tempat bertengger ketika berada di SMPR.

Karakteristik lain yang juga penting dari pohon kepuh, yaitu tajuknya yang luas namun tidak penuh, tidak terhalang atau tidak berhubungan dengan tajuk pohon lainnya. Keadaan ini bermanfaat bagi cikalang untuk menghindari serangan predator yang ada di SMPR seperti ular cincin emas atau biawak. Ular cincin emas yang biasa berpindah dari tajuk pohon ke tajuk pohon akan mengalami kesulitan mencapai pohon kepuh karena tajuknya bebas. Manfaat lain dari tajuk pohon kepuh yang luas yaitu dapat menaungi banyaknya jumlah burung cikalang yang bertengger di SMPR.

Lokasi pohon kepuh tempat bertengger burung cikalang sebagian besar ditemukan di hutan sekunder 
campuran bagian barat dan selatan SMPR. Pohon-pohon kepuh ini tidak terletak di tengah pulau, melainkan dekat dengan hutan mangrove dan berada tidak jauh dari laut. Kemungkinan dipilihnya lokasi ini karena kecepatan angin di wilayah ini cukup memadai untuk cikalang bertengger, beristirahat sampai nanti terbang kembali ke laut. Angin yang datang dari laut diduga tidak banyak berkurang dan tidak terhalang oleh formasi-formasi pohon seperti jika berada di tengah pulau. Sehingga memudahkan cikalang ketika hendak terbang meninggalkan tempat bertengger. Kondisi ini penting karena perilaku terbang dan bertengger burung cikalang sangat dipengaruhi oleh angin. Keadaan tempat bertengger burung cikalang di SMPR ini ternyata hampir sama dengan lokasi bersarang di habitat aslinya. Gibson-Hill (1947); Stokes (1988); Hill and Dunn (2004) menyatakan bahwa burung cikalang biasanya bersarang di teras-teras pantai dan jarang sampai masuk ke dalam pulau. Burung cikalang lebih memilih lokasi tempat tenggeran yang dekat dengan laut dan tidak berada di pedalaman pulau. Gibson-Hill (1947) lebih jelas menyatakan bahwa lokasi yang seperti ini memiliki kondisi angin yang baik serta tempat hinggap yang jelas karena vegetasinya tidak serapat dibandingkan di bagian dalam pulau. Sehingga mudah bagi burung cikalang untuk bertengger atau terbang dari sarangnya.

\section{ANALISIS VEGETASI DI SEKITAR TEMPAT BERTENGGER BURUNG CIKALANG}

Di sekitar lokasi pohon tenggeran burung cikalang ditemukan 11 jenis pohon. Jenis pohon beringin kresek (Ficus sp.) diketahui memiliki nilai INP yang tertinggi yaitu 16,91\%, lalu diikuti jenis koreak (Allophylus cobbe) dengan INP 16,78\% dan kayu hitam (Diospyros maritime) dengan INP 14,23\%. Dari hasil INP ini, dapat diketahui bahwa jenis yang paling mendominasi di lokasi pohon tenggeran burung cikalang adalah beringin kresek. Namun secara umum, ketiga jenis tersebut memiliki daerah sebaran yang lebih merata dibandingkan jenis-jenis yang lain. Hampir di setiap lokasi pohon tenggeran dapat dijumpai jenis kresek, koreak dan kayu hitam. Begitu pula sebaliknya dengan jenis-jenis yang memiliki INP yang rendah, seperti jenis mengkudu (Morinda citrifolia) dengan INP 2,71\% dan buta-buta (Excoecaria agallocha) dengan INP 2,21\%. Hal ini menunjukan kedua jenis ini memiliki sebaran yang terbatas dan tidak merata.

Pengaruh pohon-pohon yang terdapat di sekitar tempat bertengger burung cikalang belum diketahui secara pasti.Burung cikalang tidak mengkonsumsi buah atau biji tumbuhan, maka diduga keberadaan pohon-pohon ini tidak terlalu berpengaruh terhadap cikalang. Namun bila diperhatikan dari perilaku burung cikalang yang lebih memilih untuk bertengger di pohon kepuh, maka keberadaan jenis-jenis pohon tersebut cukup menguntungkan bagi burung cikalang. Ukuran pohon-pohon tersebut tidak lebih besar dan tinggi dibandingkan dengan jenis kepuh yang dijadikan tempat bertengger dengan kisaran tinggi 3,49-16,07 m. Kondisi ini membuat kanopi pohon kepuh bebas dan tidak terhalang kanopi pohon lain. Sehingga memudahkan burung cikalang pada saat bertengger dan ketika akan terbang kembali.

\section{KESIMPULAN}

Kesimpulan dari penelitian ini adalah: Populasi burung cikalang yang terdapat di SMPR berkisar antara 87-139 ekor. Burung cikalang memanfaatkan pohon kepuh (Sterculia foetida) untuk digunakan sebagai tempat bertengger ketika berada di SMPR. Pohon Sterculia foetida yang digunakan sebagai tempat bertengger memiliki rata-rata tinggi 23,47m; diameter 42,26 cm dan terletak di hutan sekunder campuran sebelah barat dan selatan SMPR dekat dengan hutan mangrove. 


\section{DAFTAR PUSTAKA}

BirdLife International. (2001). Threatened birds of Asia: the BirdLife International Red Data Book. Cambridge, UK: BirdLife International.

Birdlife International. (2004). Important Bird Areas in Asia: Key Sites for Conservation. Cambridge, UK: Birdlife International (Birdlife conservation Series No. 13).

BirdLife International (2009). Fregata andrewsi. In: IUCN 2010. IUCN Red List of Threatened Species.Version 2010.1.www.iucnredlist.org, 21 April 2010, pk. 10:56 WIB.

BirdLife International (2009). Fregata ariel. In: IUCN 2010. IUCN Red List of Threatened Species.Version 2010.1.www. iucnredlist.org, 21 April 2010, pk. 10:06 WIB.

Campbell, Bruce and Elizabeth Lack. (1985). A Dictionary of Birds. Buteo Books, Vermillon. Fisher, R. J., Q. E. Fletcher, C. K. R. Willis and R. M. Brigham. 2004. Roost Selection and Roosting behavior of Male Common Nighthawks. The American Midland Naturalist. 151 (1):79-87.

Garnett, Stephen T. and Gabriel M. Crowley. (2000). The Action Plan for Australian Birds 2000. Environment Australia, Canberra.

Gibson-Hill, C. A. (1947). Notes on the Birds of Christmas Island, Bulletin Raffles Museum. 18: 91-93; 122-137.

Harrison, Parker. 1983. Seabirds; An Identification Guide. Croom Helm Ltd., Beckenham.

Hill, R. and Dunn A. (2004). National Recovery Plan For The Christmas Island Frigatebird Fregata andrewsi. Commonwealth of Australia, Canberra.

Imanuddin dan A. Mardiastuti. (2003). Ekologi Bangau Bluwok Mycteria cinerea di Pulau Rambut Jakarta. Jurusan Konservasi Sumberdaya Hutan, Fakultas Kehutanan Institut Pertanian Bogor dengan Disney Wildlife Conservation and Wildlife Trust, USA.

Nelson, J. Bryan. (2005). Pelican, Cormorants and Their Relatives - The Pelecaniformes. Oxford University Press Inc., New York.

Stokes, Tony. (1988). A Review Of The Birds OfChristmas Island, Indian Ocean. Australian National Parks and Wildlife Service, Canberra. 